\title{
Relasi Manusia, Alam dan Tuhan Dalam Harmonisasi Semesta
}

Oleh :

I Gusti Made Widya Sena *)

\begin{abstract}
Abstrack
Humans and nature are two of the many symbols of the manifestation of God's love for the universe He created. The form of God's love for the universe is an indisputable reality because before God created humans, he also thought and understood the survival of human beings in the realm of life as a form of symbiotic relationship between human and natural.
\end{abstract}

All human needs have been fulfilled and provided by God through the supply of natural resources, and vice versa God is preparing humans to help maintain the balance of the universe, both physical, biological and socio-cultural elements.

The concept of Tri Hita Karana is the root of people's happiness in Bali. As a philosophy of life for Balinese people who still exist in the community in Bali, it is also used as a model of happiness in other countries in the world. This concept is a very simple to be implemented in everyday life. Because Tri Hita Karana etymologically is derived from three syllables, Tri which means "three", Hita means "happiness" and Karana which means "cause". The three causes of happiness consist of Parahyangan, Palemahan and Pawongan.

The relation of God's relationship with nature according to the Hindu perspective is God as a symbol of the bhuana agung and bhuana alit. God as a symbol of the bhuana agung (universe) is a manifestation of the contents of the universe while God as a symbol of the bhuana alit can be realized that God exists and lives in every human being.

Keywords: Human, Nature, God, Harmony

\section{PENDAHULUAN}

Manusia dan alam merupakan dua dari sekian banyaknya simbol perwujudan cinta kasih Tuhan kepada semesta ciptaanNya. Bentuk kasih Tuhan pada semesta adalah realita yang tak dapat terbantahkan karena sebelum Tuhan menciptakan manusia, Beliau juga telah memikirkan dan memahami keberlangsungan hidup manusia didalam alam kehidupan sebagai bentuk hubungan simbiosis mutualisme antara manusia dengan alam.
Segala kebutuhan manusia telah dipenuhi dan disediakan oleh Tuhan melalui persediaan sumber daya alam, begitu pula sebaliknya Tuhan mempersiapkan manusia dalam membantu menjaga keseimbangan alam semesta, baik itu unsur fisik, unsur hayati dan unsur sosial budaya.

Wujud kasih ini tentunya tidak hanya berhenti pada hubungan yang baik diantara alam dan manusia saja, melainkan juga hubungan ini dibangun dengan dasar hubungan bhakti yang benar antara manusia dengan Tuhan.

*) I Gusti Md Widya Sena, adalah Dosen Jurusan Yoga \& Kesehatan pada Fakultas Brahma Widya IHDN Denpasar 
Relasi yang dibangun berdasarkan keyakinan, pengetahuan, pemahaman, toleransi, emosi dan laku spiritual dapat mewujudkan hubungan yang harmonis menuju harmonisasi alam semesta.

\section{PEMBAHASAN}

\subsection{Penerapan Tri Hita Karana}

Konsep Tri Hita Karana adalah akar dari kebahagiaan masyarakat di Bali. Sebagai filsafat hidup orang Bali yang hingga kini masih eksis dalam komunitas masyarakat di Bali juga digunakan sebagai model kebahagiaan di negaranegara lain didunia. Konsep ini merupakan konsep yang sangat sederhana untuk diimplementasikan dalam kehidupan sehari-hari. Karena Tri Hita Karana secara etimologi berasal dari tiga suku kata, yakni Tri yang berarti tiga, Hita yang berarti kebahagiaan dan Karana yang berarti penyebab.

Dengan demikian Tri Hita Karana artinya tiga penyebab kebahagiaan. Tiga penyebab kesejahteraan hidup baik secara jasmani maupun rohani yang diwujudkan berdasarkan hubungan yang harmonis antara hubungan manusia dengan Tuhan (Parahyangan), manusia dengan sesama (Pawongan) dan hubungan manusia dengan lingkungan (Palemahan).

Ini merupakan dasar pedoman hidup yang mana setiap hubungan diantara satu dan lainnya memiliki dasar hubungan yang saling berkaitan dan selaras dalam mengembangkan keharmonisan hidup.

Hubungan yang harmonis antara manusia dengan Tuhan dapat diwujudkan dengan mengimplementasikan ajaran karma dan bhakti kepada Tuhan Yang Maha Esa. Dengan melakukan sadhana seperti melakukan persembahyangan, melaksanakan upacara, tirta yatra, dharma yatra, mempelajari, mendalami dan menerapkan ajaranajaran agama yang tersurat dalam kitab suci, mempraktekkan yoga, meditasi dan kegiatankegiatan spiritual lainnya dengan memusatkan pikiran dan menyerahkan segala hasilnya padaNya.

Hubungan yang harmonis antara manusia dengan sesama dapat diwujudkan dengan hubungan yang didasarkan atas rasa saling menghormati, menghargai, melindungi, mengasihi, meningkatkan rasa empati serta menjaga dan merawat toleransi yang telah dibangun dengan baik hingga saat ini. Berbagai konsep ramah tamah seperti paras paros sarpanaya, menyama braya dan Tat Twam Asi merupakan falsafah toleransi dan kerukunan umat Hindu yang hingga kini masih dapat diterapkan dalam mewujudkan keharmonisan masyarakat.

Hubungan yang harmonis antara manusia dengan lingkungan dapat diwujudkan dengan menjaga keseimbangan lingkungan; seperti merawat, menjaga kebersihan dan kesehatan lingkungan. Pada umumnya umat Hindu di Bali telah menjaga hubungan ini dengan melaksanakan upacara tumpek uduh (sebagai bentuk penghormatan terhadap alam yang telah menyediakan bahan pangan), tumpek kandang (melestarikan dan selamatan pada hewan) dan upacara caru (untuk membersihkan dan mengharmoniskan alam semesta).

Hubungan ketiga penyebab kebahagiaan ini dapat diilustrasikan dengan model gambar sebagai berikut:

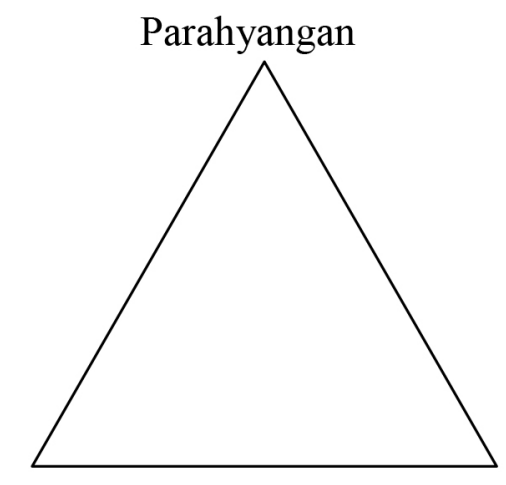

Pawongan Palemahan

Gambar 1

Model dan Hubungan Tri Hita Karana

\subsection{Relasi Tuhan dengan Alam Menurut Perspektif Hindu}

Tuhan sendiri memiliki dua aspek wujud dalam ajaran Hindu, yaitu secara vertikal dan juga horisontal. Konsep pemahaman wujud Tuhan dalam aspek horisontal dijelaskan pada konsep 
Tri Murti (Brahma, Wisnu, Iswara), sedangkan pemahaman wujud Tuhan dalam aspek vertikal disimbolkan dengan konsep yang disebut dengan Tri Purusa (Paramasiwa, Sadasiwa, dan Siwa).

Konsep pengetahuan Bhuana Agung dengan Bhuana Alit, apa yang terdapat di alam semesta ini sudah tentu juga berada dalam tubuh manusia sebagai aspek dari Bhuana Alit hanya saja bentuknya yang berbeda. Selanjutnya dalam pengetahuan Hindu, disebutkan tentang berbagai lapisan alam yang ada, baik itu Sapta Patala (lapisan Bumi ke bawah), Sapta Loka (lapisan alam semesta ke atas) dan juga yang disebut dengan tiga tingkatan Alam Semesta yakni : Bhur Loka (Alam manusia), Bhwah Loka (Alam Pitara), dan Swah Loka (Alam Dewa).

Hubungan antara Bhuana Agung dengan Bhuana Alit sebagai konsep kesimbangan dunia yang dijelaskan dalam aspek Sapta Loka atau dari alam Dewa sampai ke alam kesuniaan (kamoksan), begitu juga tingkatan alam semesta dalam tubuh manusia, penjelasannya sebagai berikut :

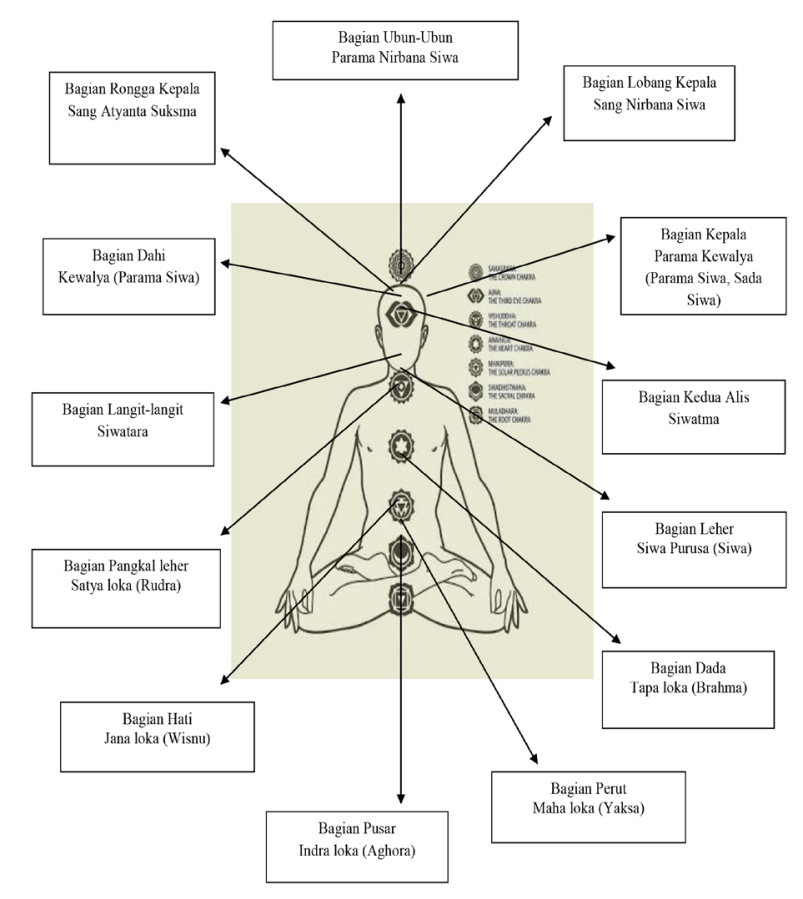

Tingkatan-tingkatan alam dalam Bhuana Agung jika dihubungkan dengan tubuh manusia (Bhuana Alit), ditemukan pada bagian-bagian tubuh manusia dari alam yang paling bawah sampai dengan yang tertinggi yaitu alam kamoksan (dari bagian tubuh manusia yaitu bagian pusar sampai dengan bagian ubun-ubun).

Pada setiap bagian yang merupakan simbol alam semesta dalam tubuh manusia bersthana Dewa-Dewa, di mana Sang Hyang Parama Nirbana Siwa adalah Dewa tertinggi yang harus dijadikan objek dalam kamoksan. Adapun tingkatantingkatan alam dalam Bhuana Agung dan Bhuana Alit sebagai replica tubuh manusia adalah sebagai berikut :

1. Bagian Ubun-ubun, Sanghyang Parama Nirbana Siwa

2. Bagian Lobang Kepala, Sang Hyang Nirbana Siwa

3. Bagian Rongga Kepala, Sang Hyang Atyanta Suksma

4. Bagian Kepala, Paramakewalya (Sang Hyang Parama Siwa dan Sang Hyang Sada Siwa)

5. Bagian Di tengah (diantara kedua alis), Sang Hyang Siwatma

6. Bagian Dahi, Kewalya (Sang Hyang Parama Siwa)

7. Bagian Langit-langit (Sang Hyang Siwatara)

8. Bagian Leher, Sang Hyang Siwapurusa

9. Bagian Pangkal leher, Satyaloka (Rudra/ Mahadewa)

10. Bagian Dada, Tapaloka (Brahma)

11. Bagian Hati, Janaloka (Wisnu)

12. Bagian Perut, Mahaloka (Sanghyang Yaksa Prajapati)

13. Bagian Pusar, Indraloka, Sanghyang Aghora.

Penjelasan tersebut berpedoman kepada penjelasan Bhuana Kosa Patalah II dari sloka 1-13, bahwa sebenarnya apa yang ada di alam semesta atau tingkatan alam yang ada di alam semesta ini sangat mempengaruhi atau saling berhubungan dengan tubuh manusia, dan dapat dikatakan saling berkaitan satu dengan yang lainnya. 
Tuhan dalam manifestasi beliau sebagai Sang Hyang Siwa (Rudra) maupun dewata lainnya memiliki tempat atau sthananya masingmasing. Konsep Sapta Patala, dan Sapta Loka di dalam lontar Bhuana Kosa menjadi bagian integral dari tempat atau sthana-Nya. Sapta patala merupakan lapisan alam ke bawah, sedangkan Sapta Loka adalah lapisan alam ke atas. Baik sapta patala maupun sapta loka juga akan mengalami peleburan ketika Sang Hyang Siwa menghendaki kehancuran alam semesta yang dinamakan dengan Maha Pralaya. Adapun tingkatan-tingkatan dari Sapta Loka dalam Bhuana Kosa meliputi :

$\begin{array}{ll}\text { 1. Bhur loka } & \begin{array}{l}\text { : Tempat manusia (alam } \\ \text { manusia) }\end{array} \\ \text { 2. Bvah loka } & \begin{array}{l}\text { Angkasa (alam pitara)Per- } \\ \text { tiwi }\end{array} \\ \text { 3. Svah loka : Alam para Dewa (Indra) } \\ \text { 4. Maha loka : Alam Dewa PrajapatiApah } \\ \text { 5.Jana loka : Alam Dewa Wisnu Teja } \\ \text { 6.Tapa loka }: \text { Alam Dewa Brahma } \\ \text { 7.Satya loka }: \begin{array}{l}\text { Alam Dewa Sangkara } \\ \text { (Siwa) Akasa }\end{array}\end{array}$

Dari adanya Sapta loka tersebut, ternyata memiliki pengaruh dari konsep Panca Maha Bhuta. Hal ini sesuai dengan tingkatan alam yang ada. Apabila dimulai dari Tri Bhuwana atau Tri loka (Bhur, Bwah, dan Swah) yang memiliki pengaruh dari pertiwi, Maha loka memiliki pengaruh Apah, Jana loka memiliki pengaruh Teja, Tapa loka memiliki pengaruh Bayu, dan Satya loka memiliki pengaruh Akasa. Semua konsep dari adanya Sapta Loka dengan Panca Maha Bhuta adalah untuk keharmonisan alam semesta ini, sesuai dengan yang dijelaskan dalam lontar Bhuana Kosa IV dari sloka 11-12.

Konsep Sapta Patala atau tujuh tingkatan alam semesta juga memiliki pengaruhpengaruhnya terhadap Panca Maha Bhuta dan keharmonisan jagat raya ini. Sang Hyang Siwa menjelaskan bahwa dalam kehidupan di Bhuana Agung dan Bhuana Alit tentunya memiliki sifatsifat untuk mempengaruhi alam semesta dan alam manusia itu, sifat-sifat seperti itu disebut dengan
Tri Guna. Tri Guna artinya tiga sifat dasar yang dimiliki oleh manusia sejak lahir.

Tri Guna akan saling bergantian mempengaruhi manusia, hal ini dapat dijelaskan dari adanya konsep Tri Guna ini dalam lontar Bhuana Kosa IV. 20, sebagai berikut :

Satwa, rajah, tamah, yeka tri guna, nga, wiparita nirguña, ya ta hetuning jagat tan wĕtu sakaring abyakta, wiparita ngaranya, yan satwa utkața, dadi manuṣa, yang tamah utkata, dadi tiryyak tika, nahan ta kramanya.

Terjemahannya:

Sattwam, Rajah, Tamah disebut dengan Tri Guna, mempunyai sifat bingung, tanpa keahlian. Itulah sebabnya alam yang lahir dari awyakta dikatakan mempunyai sifat bingung. Bila Satwam yang unggul, maka akan menjadi manusia. Bila tamah yang unggul, maka akan menjadi binatang, demikian keadaannya.

Sloka tersebut memberikan penjelasan bahwa adanya Tri Guna ini akan saling bergantian satu dengan yang lainnya untuk mempengaruhi watak manusia tersebut. Adanya Tri Guna ini tentunya harus dapat dipelajari dan dipahami dengan baik, agar nantinya dari Tri Guna ini dapat menyebabkan diri manusia tersebut masuk ke alam surga bukan sebaliknya.

Tri Guna ini juga berfungsi untuk memikirkan apakah semasa hidupnya seorang manusia telah melaksanakan kebaikan atau tidak. Penjelasan lebih lanjut tentang adanya konsep Tri Guna, ada di dalam lontar Wrhaspati Tattwa sloka 20-24, yang menjelaskan tentang dampak-dampak yang terjadi dari ketidakseimbangan Tri Guna bagi kelangsungan hidup manusia adalah sebagai berikut :

Yan sawika ikang citta, ya hetuning atma pamanggihaken kamoksan,

Apan ya nimala, dumeh ya gumayaken rasaning agama lawan wekas ning guru.

Terjemahannya :

Apabila sattwa citta itu, itulah sebabnya atma menemukan kamoksan dan kelepasan, oleh karena ia suci, menyebabkan ia melaksanakan ajaran agama dan petuah guru. 
Yapwan pada gong nikang sattwa lawan rajah, yeka matangyan mahyun magawaya dharma denya, kadadi pwakang dharma denya kaleh, ya ta matangyan mulih ring swargan, apan ikang sattw mahyun ing gawe bayu, ikang rajah manglakwaken.

Terjemahannya :

Apabila sama besarnya antara sattwa dan rajah, itulah menyebabkan ingin mengamalkan dharma olehnya, berhasillah dharma itu olehnya berdua, itulah menyebabkan pulang ke sorga, sebab tattwa ingin berbuat baik, si rajah itu yang melaksanakannya.

Yan pada gongnya katelu, ikang sattwa, rajah, tamah, ya ta matangyan pangjadma manusa, apan pada wineh kahyunya.

Terjemahannya :

Apabila sama besarnya ketiga guna, sattwa, rajah, dan tamah itu. Itulah yang menyebabkan penjelmaan manusia, karma sama memberikan kehendaknya /keinginannya.

Yapwan citta si rajah magong, krodha kewala, sakti pwa ring gawe hala, ya ta hetuning atma tibang naraka.

Terjemahannya :

Apabila citta si rajah besar, hanya marah kuat, pada perbuatan jahat, itulah yang menyebabkan atma jatuh ke neraka.

Yapwan tamah magong ring citta, ya hetuning atma matemahan triak, ya ta dadi ikang dharmasadhana denya, an pangdadi ta ya janggama.

Terjemahannya :

Apabila tamah yang besar pada citta, itulah yang menyebabkan Atma menjadi binatang, ia tidak dapat melaksanakan dharma olehnya, yang menyebabkan menjadi tumbuh-tumbuhan.

Dengan memperhatikan penjelasan dari sloka tersebut di atas maka sudah jelas yang menyebabkan adanya perbedaan kelahiran itu adalah Tri Guna (sattwam, rajah, dan tamas).

Setiap manusia memiliki Tri Guna. Sifat-sifat dalam Tri Guna yakni sifat sattwam merupakan sifat baik, sifat rajas dan sifat tamas adalah sifat yang kurang baik. Tetapi kedua sifat itu harus ada di dalam diri manusia, karena semua sifat-sifat tersebut menyebabkan manusia dapat maju dan mencapai tujuannya. Sebagai manusia yang beragama dan mempunyai tujuan mulia, hendaknya selalu berusaha meningkatkan diri ke arah yang lebih baik dengan selalu berusaha untuk memenangkan sifat sattwam dalam diri manusia.

Setelah mengetahui tentang tingkatan alam dari Tri Loka (Bhur, Bwah, dan Swah) tersebut, termasuk juga dengan adanya pengaruh Tri Guna yang mempengaruhi kehidupan seseorang dan alam semesta ini. Setiap tingkatan alam juga memiliki pengaruhnya tersendiri dan itu tidak lain merupakan perwujudan dan cerminan dari Tuhan dalam wujudnya sebagai Sang Hyang Siwa.

Keberadaan dari alam sebagai manifestasi Siwa mengambil atau berwujud sebagai Dewa Wisnu. Dewa Wisnu merupakan salah satu dewa dalam konsep Tri Murti yang tugasnya adalah untuk memelihara kelangsungan alam semesta ini, keberlangsungan kehidupan makhluk hidup dan sebagainya, maka dari itu dijelaskan dalam lontar Bhuana Kosa IV.31 tentang kemahakuasaan Tuhan dalam wujud Dewa Wisnu sebagai berikut :

Ika tang pada, tan hana len sangke ri ya, ya sinangguh Wișnu loka,nga, lwir ikang dewata hana ngkāna, pada catur muka, mwang catur bhuja, sira gumawe catur yuga.

Terjemahannya :

Alam yang demikian itu, tiada lain disebut alam Wisnu. Semua Dewa yang bersemayam di sana berkepala empat, bertangan empat. Beliau pula yang membuat empat kurun jaman (catur yuga).

Dewa Wisnu dalam tugasnya sebagai pemelihara dan pelindung alam semesta ini dengan segala isinya, dikatakan turun dan menjelma ke dunia pada setiap jaman (catur yuga). Perwujudan beliau pada saat turun kedunia disebut sebagai Avatara, yang memiliki tugasuntuk menyelamatkan umat manusia dan alam semesta dari kehancuran. Dalam wujudnya 
sebagai awatara, Dewa Wisnudikatakan sudah turun ke dunia sebanyak sembilan dari sepuluh penjelmaannya, untuk lebih jelasnya dibawah ini dijelaskan mengenai Avatara dari Dewa Wisnu dan juga pengaruhnya di setiap jaman (yuga) :

1. Inkarnasi Dewa Wisnu sebagai Matsya Awatara yang berwujud ikan yang amat besar untuk menyelamatkan bumi.

2. Inkarnasi Dewa Wisnu sebagai Kurma Awatara yang berwujud kura-kura besar sebagai penopang gunung mandara giri.

3. Inkarnasi Dewa Wisnu sebagai Varaha Awatara yang berwujud Babi Hutan Jantan yang besar.

4. Inkarnasi Dewa Wisnu sebagai Narasimha Awatara yang berwujud manusia berkepala singa.

5. Inkarnasi Dewa Wisnu sebagai Vamana Awatara yang berwujud manusia kerdil/ cebol.

6. Inkarnasi Dewa Wisnu sebagai Parasurama Awatara yang berwujud sebagai ksatriya yang sealau membawa kapak.

7. Inkarnasi Dewa Wisnu sebagai Rama Awatara yang berwujud sebagai seorang pemanah dan raja yang bijaksana.

8. Inkarnasi Dewa Wisnu sebagai Krisna Awatara yang berwujud sebagai seorang penggembala (govinda) yang membawa suling.

9. Inkarnasi Dewa Wisnu sebagai Buddha Awatara yang berwujud sebagai seorang guru spiritual.

10.Inkarnasi Dewa Wisnu yang dikatakan belum muncul adalah Kalki Awatara yang berwujud sebagai ksatrya pembunuh kejahatan di alam semesta ini (Suhardana, 2008: 15-18).

Kesepuluh awatara tersebut muncul di setiap jaman, untuk jaman Satya Yuga, awatara yang muncul adalah : Matsya Awatara, Kurma Awatara, dan Varaha Awatara. Jaman Treta Yuga, awatara yang muncul adalah :Narasimha Awatara, Vamana Awatara, dan Parasurama Awatara. Untuk
Dwapara Yuga, muncul dua awatara yakni : Rama Awatara, dan Krisna Awatara, dan untuk jaman Kali Yuga terdapat dua awatara yang muncul yakni Buddha awatara dan juga Kalki Awatara.itu semua merupakan penjelasan dari Jana Loka (alam Dewa Wisnu).

Tingkatan alam yang dibahas selanjutnya adalah alam yang disebut dengan Tapa Loka (alam Brahma), yang dimana dalam alam ini, dewa-dewa yang ada di alam Tapa Loka ini memiliki sifat yang dinamakan dengan Asta Aiswarya. Secara umum pengertian Asta Aiswarya merupakan delapan sifat kemahakuasaan Tuhan. Seperti yang dijelaskan dalam lontar Bhuana Kosa IV. 37, sebagai berikut :

Sang dewata hana ngkāna, kinahanan ta sira dening kāșțeśwaryyan,

mwang așta guṇa, tar pahinghan tejanira, lwir sang rĕși hana

ngkāna mahā sūksma, paḍa mangulahakěn kabrāhmācāryyan,

paḍ mangunyakĕn brahmā mantra, Bamadewa wijanya, Ong Bang namah.

Terjemahannya :

Dewa-dewa yang ada di sana semua memiliki delapan keunggulan (asta aiswarya) dan delapan keahlian (asta guna). Sinar-Nya sangat luar biasa, resi-resi yang ada disana sangat halus dan semua menekuni ajaran Ketuhanan dan mengucapkan mantra Brahma.

Pengertian selanjutnya mengenai Asta Aiswarya yang ada pengaruhnya terhadap alam Tapa Loka memiliki pengertian sebagai delapan sifat kemahakuasaan dari Tuhan Yang Maha Esa yang meliputi :

1. Anima artinya sifat Tuhan maha kecil.

2. Laghima artinya sifat Tuhan maha ringan.

3. Mahima artinya sifat Tuhan maha besar.

4. Prapti artinya sifat Tuhan menjangkau segala tempat.

5. Prakamya artinya sifat Tuhan segala kehendaknya selalu tercapai.

6. Isitwa artinya sifat Tuhan maha utama.

7. Wasitwa artinya sifat Tuhan maha kuasa. 
8. Yatra Kama Wasayitwa artinya sifat Tuhan segala kehendaknya pasti terlaksana (Tim Penyusun, $2007: 6$ ).

Tingkatan alam dari Sapta Loka selanjutnya adalah alam Satya Loka. Tingkatan alam ini memiliki sifat sangat utama dan sangat gaib, tanpa batas, dan sulit untuk dapat mengetahui atau memikirkannya. Pada tingkatan alam ini memiliki penggambaran dan penjelasan yang memiliki ciri khas bahwa yang bersthana atau yang menempati alam ini adalah Sang Hyang Siwa (Dewa Siwa). Ini dikarenakan terlihat jelas dari penjelasan lontar Bhuana Kosa IV. 46, sebagai berikut :

Paḍa ta sirā cihna wrěsabha dhwaja, paḍa mawāhanang lěmbu, kulawu ta sira dening bhasma, ya pinaka bhūṣaņa nira, paḍa mārddhacandra jața nira, makweh rūpa nira, pada ta lituhayu pari pūrñna sira.

Terjemahannya :

Semua bendera yang menggambarkan lembu, semua menunggang lembu, kulit beliau ke abuabuan karena diparam oleh abu, itu merupakan pakaian beliau, rambut dijalin menyerupai bulan sabit, beraneka rupa beliau, semua sangat tampan dan sempurna.

Senada dengan berbagai kutipan sloka dari Teks Bhuana Kosa tentang hubungan Tuhan dengan alam semesta, didalam Taitiriya Upanisad juga dinyatakan :

Yato va imani bhùtani jayante

yena jatani jivanti

yat prayanty abhisam visanti

tad vijijnasasva, tad brahmeti

Taittirìya Upaniûad III. 1

Terjemahan :

Dari mana semua yang ada ini lahir, dengan apa yang lahir ini hidup, kemana mereka ketika kembali, ketahuilah, bahwa itulah Tuhan Yang Maha Esa.

Lebih jauh di dalam Mundaka Upanisad II.1.10 dinyatakan : 'Purusa evedam visvam' yang artinya : Alam semesta adalah wujud Tuhan sendiri. Ruang Waktu adalah Tuhan Yang
Maha Esa. Ia menjadi immanent di dalam alam semesta ini. Tuhan Yang Maha Esa dinyatakan sebagai penguasa alam semesta, abadi dan sumber kesadaran itu sendiri. Hal ini dinyatakan di dalam Aitareya V. 3 sebagai berikut :

Sarvam tat prajnanetram prajñàne pratiûphitam prajña netro lokah.

Aitareya Upaniûad V. 3

Terjemahan :

Tuhan Yang Maha Esa sebagai yang Maha Mengetahui. Sangat luhur mengatasi alam semesta. Tuhan Yang Maha Esa tidak terbatas dan kesadaran abadi. Segalanya dikuasai oleh kesadaran ini. Kesadaran abadi adalah alam segalanya. Brahmàn adalah kesadaran Yang Agung itu.

Dalam Chandogya Upanisad III.14.3 dinyatakan sebagai berikut "Sarwam khalvidam Brahman", yang artinya "Semuanya ini adalah Brahman". Biarlah seseorang yang memujanya sebagai permulaan, akhir dan bernapas di dalamnya (Brahman). Segalanya ini sesungguhnya adalah Brahman, Tidak ada yang lain kecuali Brahman dan atman.

Dalam Brhadaranyaka Upanisad 3.9.28 dinyatakan: 'satyam jnanam anantam Brahma, vijnanam anandam Brahma', yang artinya Brahman adalah kebenaran dan pengetahuan tak terbatas, pengetahuan tertinggi dari kebahagiaan.

Dalam lontar Bhuana Kosa II. 18, dijelaskan sebagai berikut :

Kaste kasteya tha bahnih, suksmatwam upalabhyate, bhute bhute

Mahadewah, suksma geno upalabhyate. Sang hyang apuy hane rikang kayukayu, ndatan katon, maka nimitta suksmanira, yatha, kadyangga ning akasa, mangkana ta Bhatara Mahadewa, an hana ring sarwwa mawak, ndatar kapungguh sira, maka nimitta ng suksma nira.

Terjemahannya :

Api pada kayu, tetapi tidak kelihatan, karena sangat halus, itulah ibarat angkasa. Demikianlah Sang Hyang Mahadewa, ada pada semua yang 
berwujud, tetapi Beliau tidak tampak, karena kehalusan Beliau.

Dari berbagai kutipan di atas, jelas bahwa Tuhan Yang Maha Esa (Siwa) adalah pencipta alam semesta, sumber dari segalanya. Alam semesta ini pada hakekatnya adalah wujud dari wujud dari mayaNya, segalanya diliputi dan berada di dalamNya.

\section{SIMPULAN}

Relasi manusia, alam dan Tuhan dapat diwujudkan dengan konsep Tri Hita Karana artinya tiga penyebab kebahagiaan. Tiga penyebab kesejahteraan hidup baik secara jasmani maupun rohani yang diwujudkan berdasarkan hubungan yang harmonis antara hubungan manusia dengan Tuhan (Parahyangan), manusia dengan sesama (Pawongan) dan hubungan manusia dengan lingkungan (Palemahan).

Ini merupakan dasar pedoman hidup yang mana setiap hubungan diantara satu dan lainnya memiliki dasar hubungan yang saling berkaitan dan selaras dalam mengembangkan keharmonisan hidup.

Relasi hubungan Tuhan dengan alam menurut perspektif Hindu adalah Tuhan sebagai simbol bhuana agung dan bhuana alit. Tuhan sebagai simbol bhuana agung merupakan wujud isi alam semesta sedangkan Tuhan sebagai simbol bhuana alit dapat diwujudkan bahwa Tuhan ada dan hidup dalam diri setiap insan manusia. 